\title{
UMA HISTÓRIA DENTRO DA OUTRA, UMAS GEOGRAFIAS QUE SE ESBARRAM: O ANIVERSÁRIO DE ZUZA: UMA MARIONETE QUE QUERIA SER PRÍNCIPE! ${ }^{(*)}$
}

\author{
Jader Janer Moreira Lopes ${ }^{1}$ \\ Marcos Chica Diaz ${ }^{2}$ \\ Nilcéa Beatriz Braga ${ }^{3}$
}

A educação é o ponto em que decidimos se amamos o mundo o bastante para assumirmos a responsabilidade por ele e, com tal gesto, salvá-lo da ruína que seria inevitável, não fosse a renovação e a vinda dos novos e dos jovens. A educação é, também, onde decidimos se amamos nossas crianças o bastante para não expulsá-las de nosso mundo e abandoná-las a seus próprios recursos, e tampouco arrancar de suas mãos a oportunidade de empreender alguma coisa nova e imprevista para nós, preparando-as em vez disso com antecedência para a tarefa de renovar um mundo comum.

ARENDT, Hannah. A crise na educação: III e IV. Entre o passado e o futuro. São Paulo: Perspectiva, 1972, p. 247.

Temos um grande título! Temos uma epígrafe! Precisamos escolher por onde começar! Principiar! Todo texto pressupõe um início, mesmo que não sejam os clássicos. Não estamos questionando esses tipos de começos, amamos muito que os usem, basta lembrar o "Era uma vez", mas falamos de uma inauguração, um instaurar para poder dar às nossas palavras a existência do encontro. Escolhemos a epígrafe para isso, invertemos os sentidos da leitura, falaremos com Hannah Arendt para, depois, retornar aos vocábulos do título!

Nascida na Alemanha, de origem judaica, em outubro de 1906, ela viveu até os 69 anos, quando veio a falecer na cidade de Nova Iorque, Estados Unidos, onde recebeu abrigo, após sua saída do território europeu frente ao crescimento do movimento nazista. A vida dessa mulher é bastante conhecida do público acadêmico e em diversos outros círculos sociais. Teve grande

\footnotetext{
${ }^{(*)}$ Financiamento: FAPEMIG.

${ }^{1}$ Universidade Federal de Juiz de Fora. ORCID: https://orcid.org/0000-0003-3510-8647.

E-mail: jjanergeo@gmail.com.

${ }^{2}$ Universidade Autônoma de Madri. ORCID: https://orcid.org/0000-0003-2423-777.

E-mail: marcoschicadiaz @ gmail.com

${ }^{3}$ Secretaria de Educação de Juiz de Fora, ORCID: https://orcid.org/0000-0003-0453-7940 .

E-mail: nilceabeatriz@gmail.com
} 
produção que impactou e impacta diversos postulados, abordando, de forma crítica e intensamente reflexiva, nossos tempos e espaços, permitindo-nos compreender muitos temas da contemporaneidade.

Selecionamos esse trecho de suas escrituras para a epígrafe, um excerto muito conhecido, que nos interessa pelo sua dimensão educativa, por falar das crianças e das redes sociais, históricas e geográficas que forjam as essências humanas; por tratar dos compromissos geracionais entre as pessoas; por narrar das fronteiras; dos entres que fazem a vida ser vida, mas, sobretudo, por expor para todos nós, aquilo que Bakhtin (2012) também nos brindou em seus trabalhos: a atitude responsável para com os outros e outras.

Uma atitude que se calca na relação de alteridade, que promove a transformação e a completude do humano, um ser marcado pela linguagem e pelo constante limiar do escorregar das brechas das narrativas universais que acometem a humanidade à luz da modernidade. Escalas de enunciações que, mesmo variando em suas dimensões e amplitudes, são sempre axiológicas. Arenas possíveis de serem fragmentadas e fragilizadas nos liames, nas unidades que tornam tecem pessoas. Escutemos algumas de suas palavras:

A falsidade e a mentira que inevitavelmente transparecem na inter-relação consigo mesmo. Imagem externa ao pensamento, do sentimento, imagem externa da alma. Não sou eu que olho o mundo de dentro com os meus próprios olhos, mas sou eu que olho a mim mesmo com os olhos do mundo, com os olhos alheios, eu sou possuído por um outro. Não há aqui uma integridade ingênua do exterior e interior. Espreitar a sua imagem em ausência. A ingenuidade da confluência de si mesmo e do outro, na imagem do espelho. Excedência do outro. Eu não tenho um ponto de vista sobre mim mesmo de fora, não tenho uma aproximação de minha imagem interior. Dos meus olhos olham os olhos alheios. (BAKHTIN, 2019, p.51)

É na "excedência do outro" que se aporta a educação, seja ela qual for: institucionalizada em escolas, em centros universitários, em templos diversos, na vida cotidiana, nas ruas, nas redes virtuais e em tantos outros locais. Educação que potencializa a precariedade do nascer humano como um compromisso, que permite e concede as transformações, o ir além de si mesmo! Por isso, a "educação é o ponto em que decidimos" (ARENDT, 1972, p. 247), o que nos faz não ter álibi (BAKHTIN, 2012), pois sempre haverá uma escolha, uma deliberação que pode levar à ruína, à destruição, ao crescimento, à renovação, à conversão, à...

E ao não álibi do humano, temos as crianças e nossas decisões para/com elas (ARENDT,1972)! Lembremo-nos aqui de um outro pensador bielorrusso: Vigotski. Ele nos evoca 
ao ato do encontro, quando nos diz que o nascimento de um bebê está sempre no intermezzo do fim de muitas histórias humanas e no início de abundantes outras. É, aí, nesse ponto geo-histórico que a gênese da vida emerge, que as crianças podem encontrar os elementos que outorgam as personalidades, as vivências. (VIGOTSKI, 2010). Por isso, a "educação é, também, onde decidimos se amamos nossas crianças o bastante para não expulsá-las de nosso mundo e abandoná-las" (ARENDT, 1972. p. 247).

E, assim, podemos voltar ao começo! Reiniciar este texto a partir de seu título. Dissemos que era um grande título. Na língua portuguesa, a palavra grande pode significar muitas coisas, desde sua caracterização métrica, até as suas dimensões de intensidades. As coisas do mundo são medidas com diferentes coisas desse mundo. Nesses contornos, as diferenças estão localizadas. Nosso título tem isso tudo: é composto por muitas palavras, mas também por muitas pujanças. E não poderia ser de outra forma, pois é um entrelace de muitas vidas que tem como protagonista um artefato cultural: o boneco Zuza!

Mas quem é Zuza? Qual sua origem? Para responder a essas questões, teremos que abandonar a narrativa em primeira pessoal do plural e convocar a primeira do singular! Não é uma simples mudança gramatical, mas uma mudança de narradores para narradora! Mesmo reconhecendo que nunca se perde a polifonia do viver (BAKHTIN, obras diversas), colocamo-nos na condição de escuta, para sentir as atitudes que o fazem criar. Espiemos das bordas dos parágrafos a conversa que segue.

Desde bem pequena, recebi de minha mãe o título de "inventadeira de moda". Na verdade, era um jeito de repreender as desarrumações de uma criança curiosa, imaginativa, buscadora de segredos escondidos num quintal propício às histórias, um palco cheio de árvores, passarinhos, pedrinhas, grama, areia e terra batida.

Ali cresci, contando e ouvindo histórias, inventando músicas, fazendo teatrinhos que demoravam mais para serem planejados e organizados do que para serem apresentados.

Cresci e escolhi ser professora e, consequentemente, contadora de histórias. Porque as histórias sempre me acompanham. Compartilhar aprendizagens a partir de elementos lúdicos é algo que faz parte da minha prática com as crianças. Dessa forma, as diferentes linguagens, como as brincadeiras, as canções, as dramatizações, as vivências cotidianas vão sendo tecidas a partir das ideias brotadas no solo fértil de um currículo cheio de vida, construído entre as crianças e todos os envolvidos. 
No caso do Zuza, como vemos no início de alguns filmes, poderíamos dizer que se trata de uma história baseada em fatos reais.

Na minha adolescência e juventude, participei de um grupo de jovens ligado à igreja católica de meu bairro. Um grupo alegre, dinâmico, cheio de atividades em que nos envolvíamos com grande entusiasmo, como gincanas e festas beneficentes, encontros de reflexão, passeios. Aos domingos, o grupo todo se reunia para cantar durante a missa ao som dos violões maravilhosamente tocados por alguns desses jovens. Imagino que nenhum deles tenha, algum dia, frequentado aulas desses instrumentos, como eu, que aprendi perguntando para um e outro como se fazia tal posição. Zuza, um amigo muito querido de todos, era um desses violonistas. Branco, cabelo cacheado, sorriso no rosto, prestativo. Não sei por que motivo, ele sempre gostava de usar uma calça camuflada, coturnos, uma jaqueta. Acho que ganhara de alguém e usava com gosto. Nunca soube ao certo sua profissão. Uma vez me disse que estava trabalhando numa fábrica de meias. Só me disse.

As mães e pais dos jovens eram carinhosamente chamados de tias e tios por todos. Quando alguém fazia aniversário, despedíamo-nos como se fôssemos dormir, mas, daí a meia hora, estávamos em frente à janela do aniversariante, fazendo uma bela serenata. O homenageado abria a janela com cara de surpresa e sempre servia um café ou alguma iguaria. Esse era um dos momentos mais esperados. Só perdia pela ansiedade que sentíamos ao vermos a janela se abrindo. Acho que era algo parecido com o que eu sentia quando preparava as histórias para serem apresentadas nos teatrinhos do quintal. Uma sensação de ter levado a infância comigo e todos os sentimentos que o ser criança provoca, de não ter deixado o título de inventadeira para trás, lá no meio das árvores, que agora já não existem mais, mas que fazem a ressurreição agora em minhas palavras.

Às vezes sinto que o lugar de professora que ocupo todos os dias é ocupado ao mesmo tempo pelas crianças. Criamos juntas, dialogamos, pensamos e realizamos sonhos. Muitas vezes sou interrompida durante as histórias para que seja colocada alguma observação.

Depois tenho que pegar o fio novamente, mas não posso desconsiderar os argumentos dos ouvintes. A partir deles, posso contar outras histórias e fazer novas descobertas em relação a tantas coisas presentes na lógica do pensamento infantil.

E por falar em fio, eu mesma consigo me interromper e preciso voltar à serenata que me trouxe a sensação boa e que, por sua vez, fez-me lembrar da minha infância e das crianças.

Acontece que o tempo passou, muitos jovens se casaram, mudaram de cidade, foram trabalhar fora, o grupo acabou se desfazendo. Eu me casei, tive uma filha e um filho. O Zuza continuou morando no bairro, encontrávamo-nos de vez em quando pelas ruas ou em algum evento 
e nos sopros dos ventos. Veio à minha casa algumas vezes para repassar umas músicas para meu filho que também se interessou por violão. Sempre me cumprimentava estendendo a mão e me chamando de Nil.

Até que um dia veio a notícia: Zuza tinha sido encontrado sem vida na calçada. Sentiu-se mal, teve um súbito que o levou. Esses ventos!

Fiquei triste! Meu filho perto de mim, sensibilizado, disse-me, como encontrando uma forma de dar alegria àquele momento de dor: "Eu vou mandar fazer um Zuza pra você! Você o leva pra escola, as crianças vão gostar!”

Daí a algum tempo, ele entregou-me Zuza! Eu mesma tinha dado suas características para a bonequeira! Abracei-o, levei-o para a escola e até hoje ele continua a viver em meio às crianças. $\mathrm{O}$ mesmo vento que o levou o trouxe de volta.

Desse jeito, com esse jeito, é o Zuza. Um boneco tecido em panos, que vive da morte e do nascimento. Como podem perceber, ele não é diferente de nenhum de nós. Todos estamos nesses ensejos. Sendo tocados por esses ventos de morrer e nascer. Esse é o presente dele para nós, por ter sido tocado por essas condições está sempre por aí, fazendo da morte a vida, tendo a criação como a infinitude.

Para contar sobre esse compromisso do Zuza, vamos continuar percorrendo nosso título. Já está claro que tem muitas histórias (tempos) e geografias (espaços) que se fazem nos esbarrões, afinal foi assim que Zuza nasceu, criando vidas dentro de vidas. E, como já expresso, todo nascimento é o principado, a instituição de um novo que nossa cultura ocidental sempre comemora. Cantemos o nascimento de Zuza, a partir de um de seus desejos: o de ser príncipe.

Esse acontecimento fez parte de um maior, um conjunto de atividades de literatura, músicas e narrativas que vem sendo desenvolvido há alguns anos por uma professora totalmente dedicada à infância e educação no Brasil ${ }^{4}$. E ele acontece em uma escola localizada no munícipio mineiro de Juiz de Fora, na região da Zona da Mata. Os mapas a seguir demarcam espacialmente a localidade.

\footnotetext{
${ }^{4}$ Trata-se da professora Nilcéia, que divide conosco a autoria deste texto.
} 
MAPA 01: JUIZ DE FORA NO BRASIL.

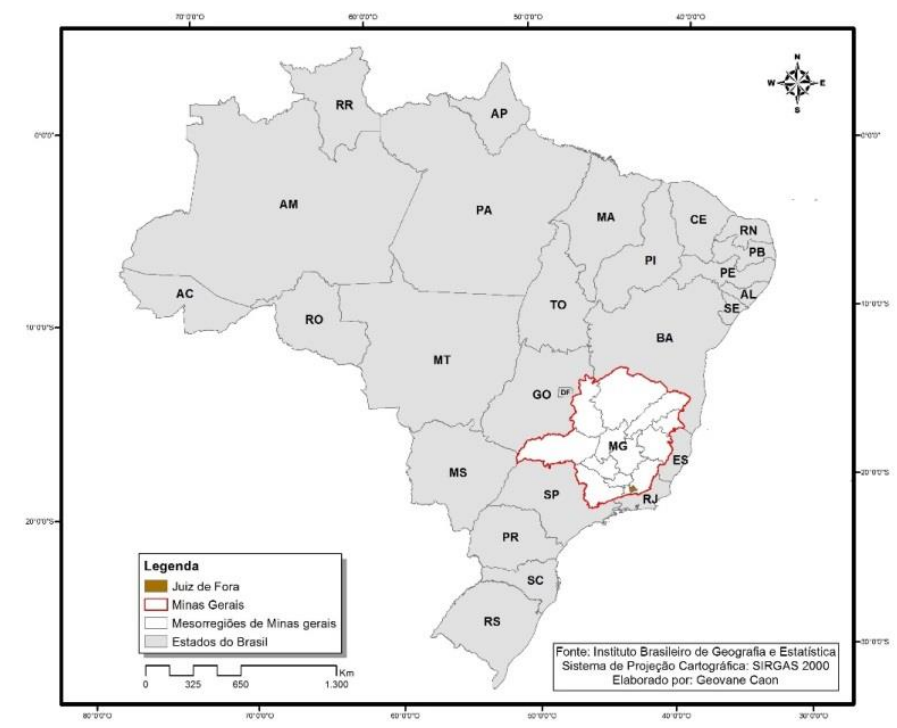

MAPA 02: JUIZ DE FORA EM MINAS GERAIS E ZONA DA MATA.

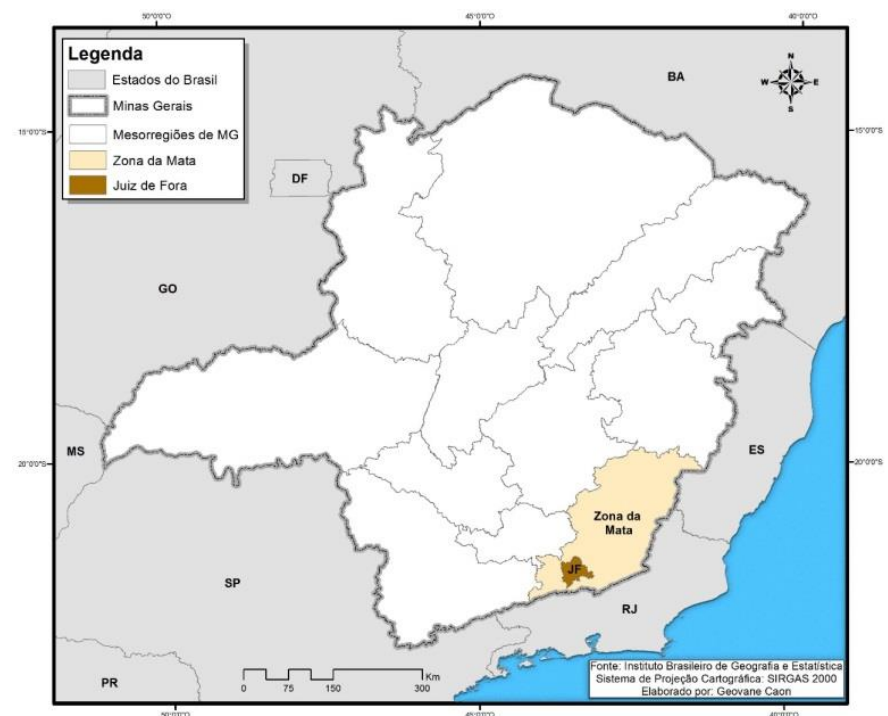

A escola é um espaço de Educação Infantil e possui também uma turma do primeiro ano do Ensino Fundamental. É uma escola pública vinculada à Secretaria de Educação do município de Juiz de Fora. Suas crianças moram nos entornos, em uma região do espaço urbano chamado de Cidade Alta, toponímia marcada pelo relevo da cidade, que se originou nos contornos do Rio Paraibuna e que se expandiu para locais de maior altitude. 
FOTO 01: A ESCOLA.

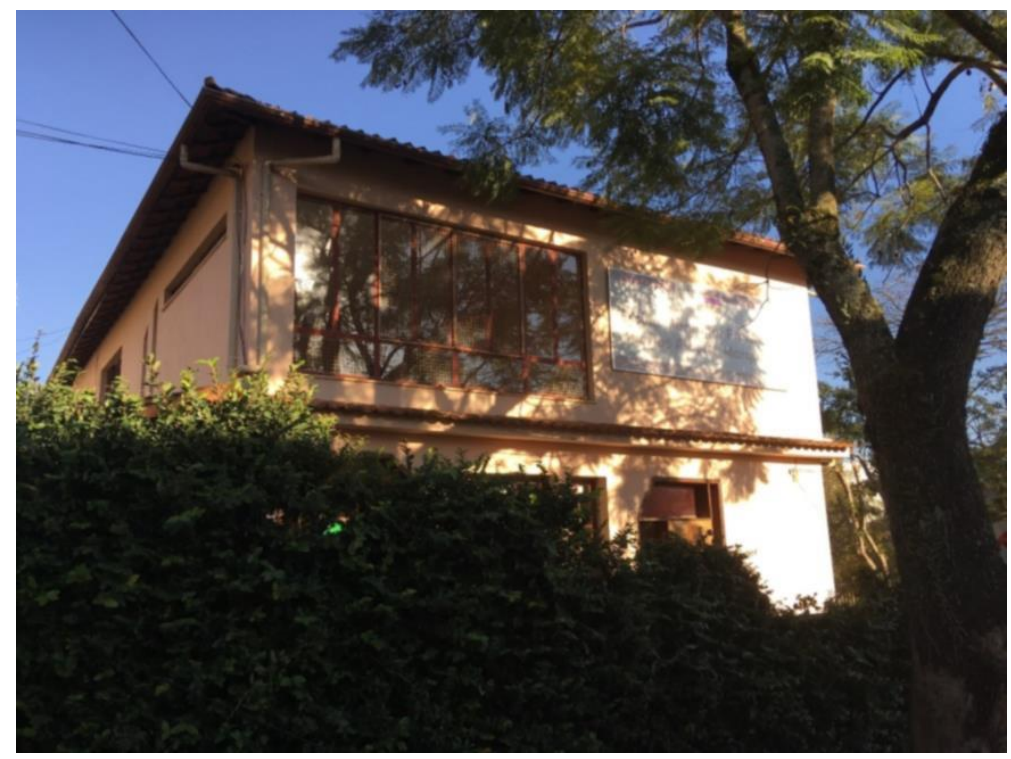

Arquivo GRUPEGI -2019.

Assim, a cada segunda e quarta-feira, as diferentes classes que compõem a escola, nomeada por Carlos Alberto Marques, desenvolvem um projeto cujas atividades envolvem histórias com personagens diferentes, canções e danças, tudo acompanhado por notas musicais suaves do violão. Apesar de sempre acontecerem novidades, um personagem está sempre presente:

Nos dias em que estou na escola ele fica no portão recebendo as crianças e as famílias com sua voz grossa e seu jeito brincalhão. Diz bom dia, boa tarde, faz comentários o tempo todo e acaba arrancando sorrisos até de alguns adultos que chegam sérios, talvez preocupados com algum problema. Ouço as crianças explicando: "É o Zuza! Ele faz muita gracinha”! Os próprios pais, com o passar do tempo, já o cumprimentam: "Oi Zuza! Como vai Zuza"? (Nota escrita para este texto)

O momento educativo que é propiciado com este projeto de literatura através da linguagem narrativa é um espaço para a construção de conhecimentos do mundo, experiência coletiva, emoção, construção da linguagem, troca de ideias, aceitação, de participação, de solidariedade, de comunicação com a expressão corporal, de conservação do patrimônio cultural, em suma, da própria da vida das crianças.

Muitas vezes são usados objetos que ganham vida e se tornam coisas ou personagens, tais como: barbeiros, fadas, princesas, rainhas, cavaleiros, príncipes, bruxas, mágicos ou outros personagens literários. As crianças participam diretamente com suas opiniões, vivenciando músicas, danças ou sendo personagens presentes nas muitas narrativas propostas. 
FOTO 02: ATIVIDADES COM AS CRIANÇAS.

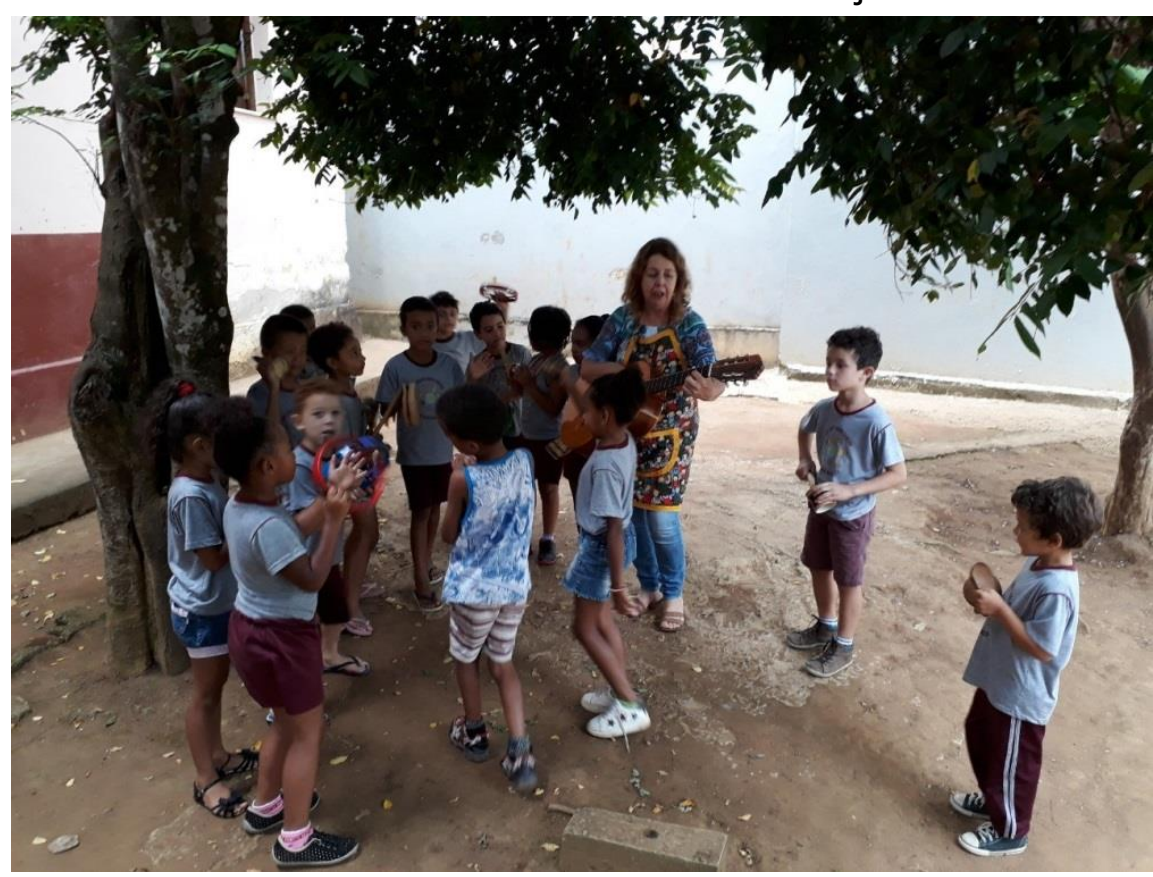

Arquivo Escola Carlos Alberto Marques -2019

Os afazeres buscam estabelecer uma metodologia de participação de todo o grupo, o que leva ao movimento dos corpos, formas de criação, de invenção das danças, das infindas linguagens que fazem parte do ser criança.

Acreditando na partilha, em muitos momentos do projeto, são criados desafios ou algumas atividades contínuas a serem realizadas envolvendo todos os profissionais da escola ou da própria sala de aula. Esse tipo de atividade procura ser mais didático e curricular. Por exemplo: eles devem escolher um nome para as fadas, eles devem escolher e escrever com o professor as perguntas que vão fazer em algum evento, ou fazer cartazes, desenhos ou outras propostas.

\footnotetext{
${ }^{5}$ Os autores do texto agradecem as fotos cedidas gentilmente pela escola. Todas as crianças possuem autorização para uso de suas imagens.
} 


\section{FOTO 03: ATIVIDADES COM AS CRIANÇAS.}

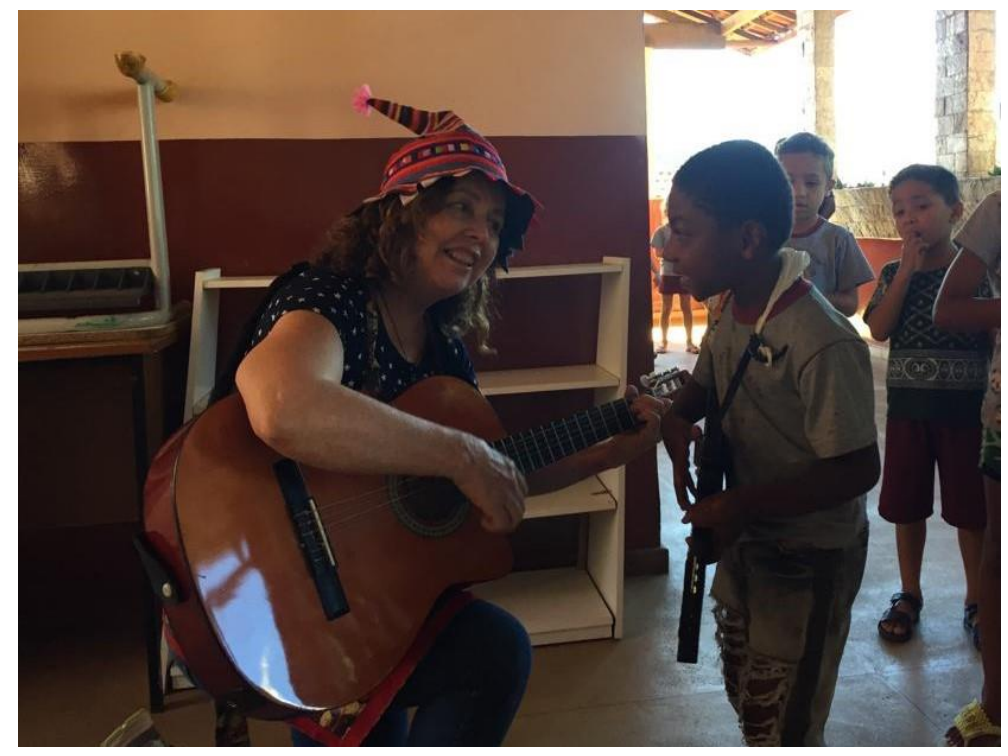

Arquivo Escola Carlos Alberto Marques, 2019.

FOTO 04: ATIVIDADES COM AS CRIANÇAS.

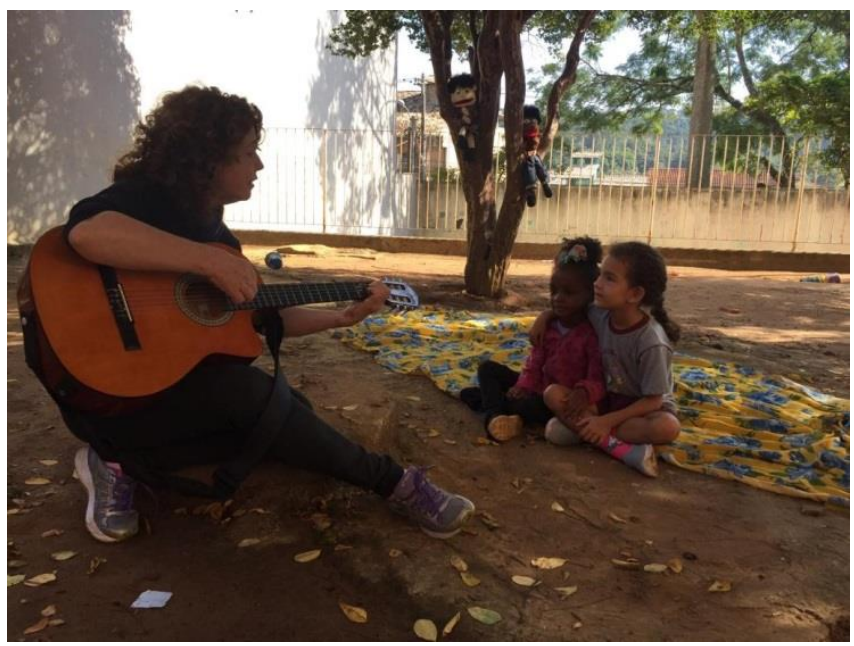

Arquivo Escola Carlos Alberto Marques, 2019.

As conversas geradas durante as narrativas e todo o conjunto de situações que ocorrem neste trabalho abrem uma dimensão de diálogo, de trânsito entre muitas paisagens desse mundo, de seus territórios, de povos e pessoas com muitas histórias encontrando a imaginação e a criatividade da criança. E, se voltarmos a Vigostki, (2009), lembraremos uma de suas passagens clássicas, ao afirmar que, quanto mais ricas as experiências vividas pelas crianças, mais material estará disponível para sua imaginação, potencializando o combinar de memórias, experiências e muitas situações que permitem vivências fartas (VIGOTSKI, 2018). 
Contudo, este texto tem um foco: o aniversário de Zuza e seu desejo de ser príncipe. Talvez precisaremos começar a história de novo, agora com "Era uma vez", mas, repetindo o já feito, deixaremos para você, leitor, procurar o que vem depois, pois já vamos para o meio da narrativa. Eis:

La madre del príncipe le dijo a la princesa:

-No te preocupes linda niña, dormirás en una cama cómoda y confortable.

Así la madre colocó 20 colchones, uno encima de otro

¿Me ayudáis a contar, niños? pregunta la profesora

Siiii- responden todos los niños

Y todos los niños de la clase comenzaron a contar:

$1,2,3,4,5,6,7,8,9,10, \ldots$

¿Cuántos colchones eran?-pregunta la profesora;

20. Todos responden, y siguen contando:

$11,12,13,14,15,16,17,18,19$ у...20

Entonces colocó una piedra bajo los 20 colchones, ¿Sabéis niños que solo las verdaderas princesas notan cualquier granito? (Nota de campo. Marzo 2019). ${ }^{6}$

\footnotetext{
${ }^{6}$ Essas notas fazem parte da observação de campo de Marcos Diaz Chica, produzidas em seu estágio doutoral na Universidade Federal de Juiz de Fora. Mantemos a grafia em espanhol, língua primeira do pesquisador citado.
} 


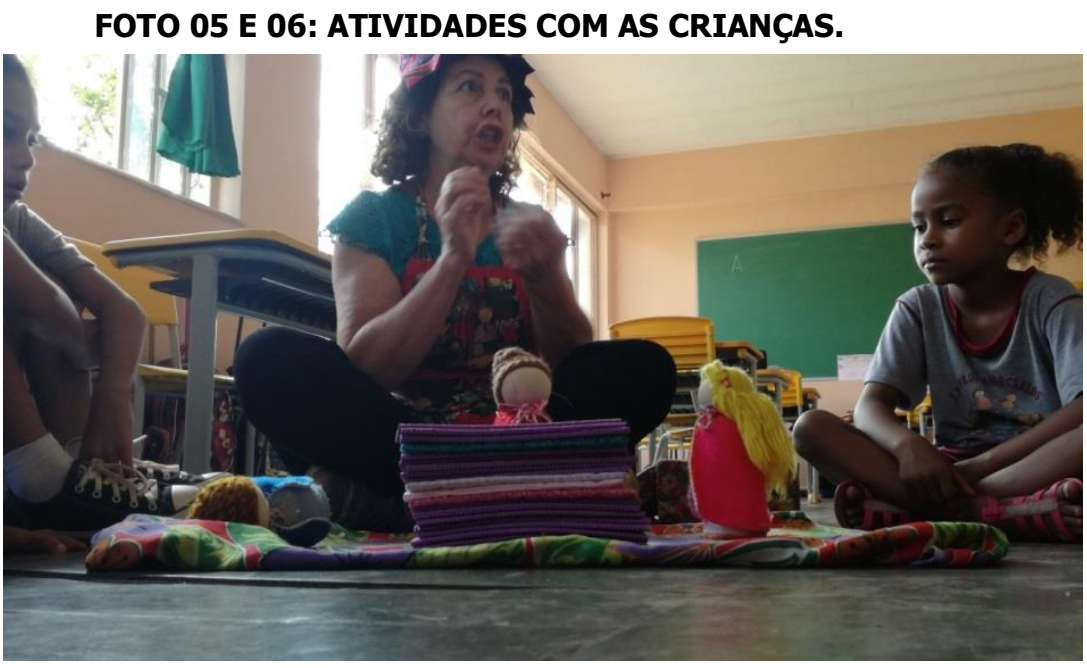

Profesora Nilcéa narrando la historia del príncipe que se quería casar con una verdadera princesa a un grupo de Primer curso, 6 años del primer turno, en la Escuela Alberto Carlos Marques. Fuente: Cuaderno de campo. Marcos Chica Díaz. Marzo 2019.

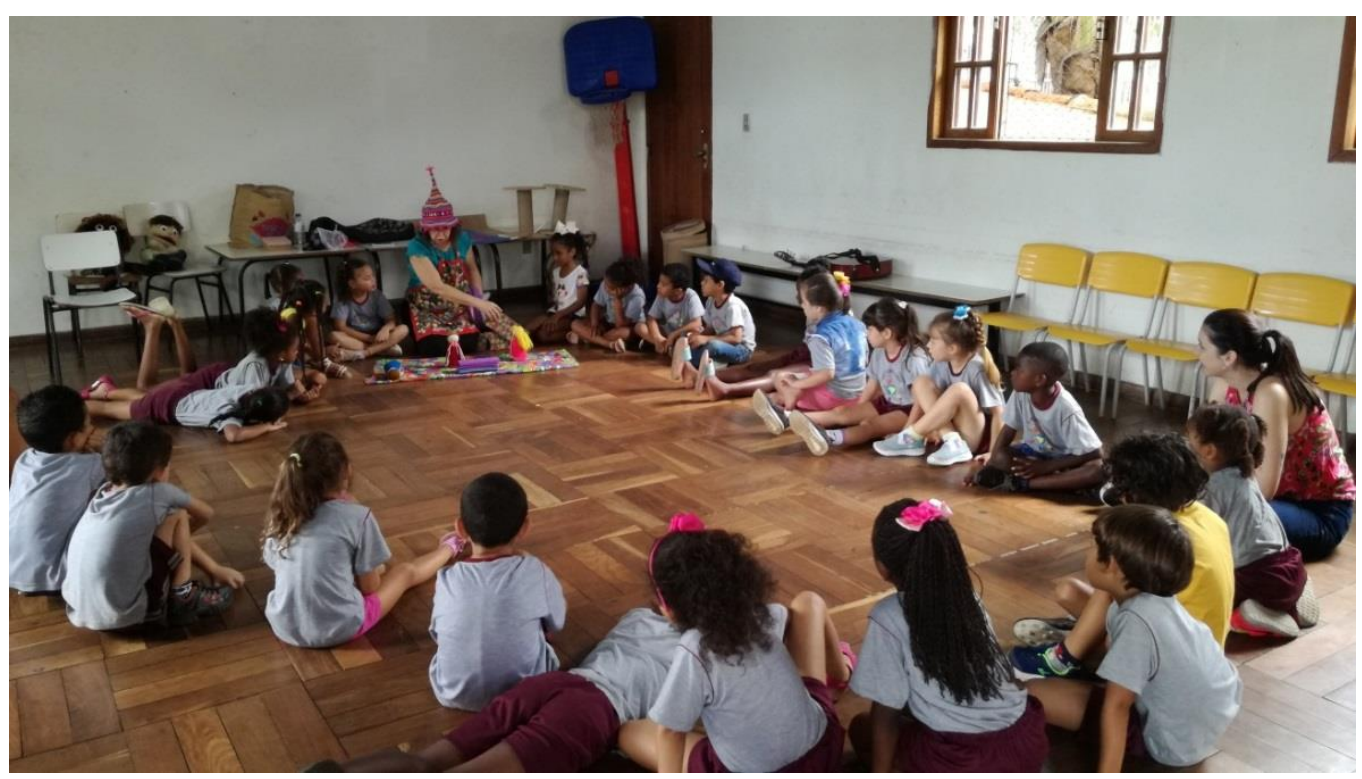

Profesora Nilcéa narrando misma historia del príncipe que se quería casar con una verdadera princesa, a otro grupo de la Creche de 5 años. Segundo Turno. Fuente: Cuaderno de campo. Marcos Chica Díaz. Marzo 2019

E foi com histórias como essas e muitas outras, que Zuza veio desenvolvendo o desejo de ser príncipe que foi aumentando na medida que se aproximava seu aniversário! E um outro encontro aconteceu: uma pessoa que estava na escola, vinda de terras longes, que falava meio embolado, também professor de crianças pequenas, mas separadas daquelas crianças por um grande oceano, resolveu comentar sobre os cavalos que muitos príncipes gostavam de montar e que, um dia, fizera uns cavalos com as crianças de sua escola. Essas palavras bastaram. Foi só ele dizer isso para que o Zuza tomasse uma decisão: naquele aniversário, ele daria de presente um cavalo para cada criança daquela escola que o acolhera. 
Zuza chamou todos os seus amigos bonecos e todos os seus amigos gente para isso. Todo mundo se envolveu intensamente, não só com o aniversário, mas também com a preparação dos cavalos. As fotos a seguir mostram um pouco de tudo isso:

FOTOS 06 E 07: AMIGOS E AMIGAS DE ZUZA.
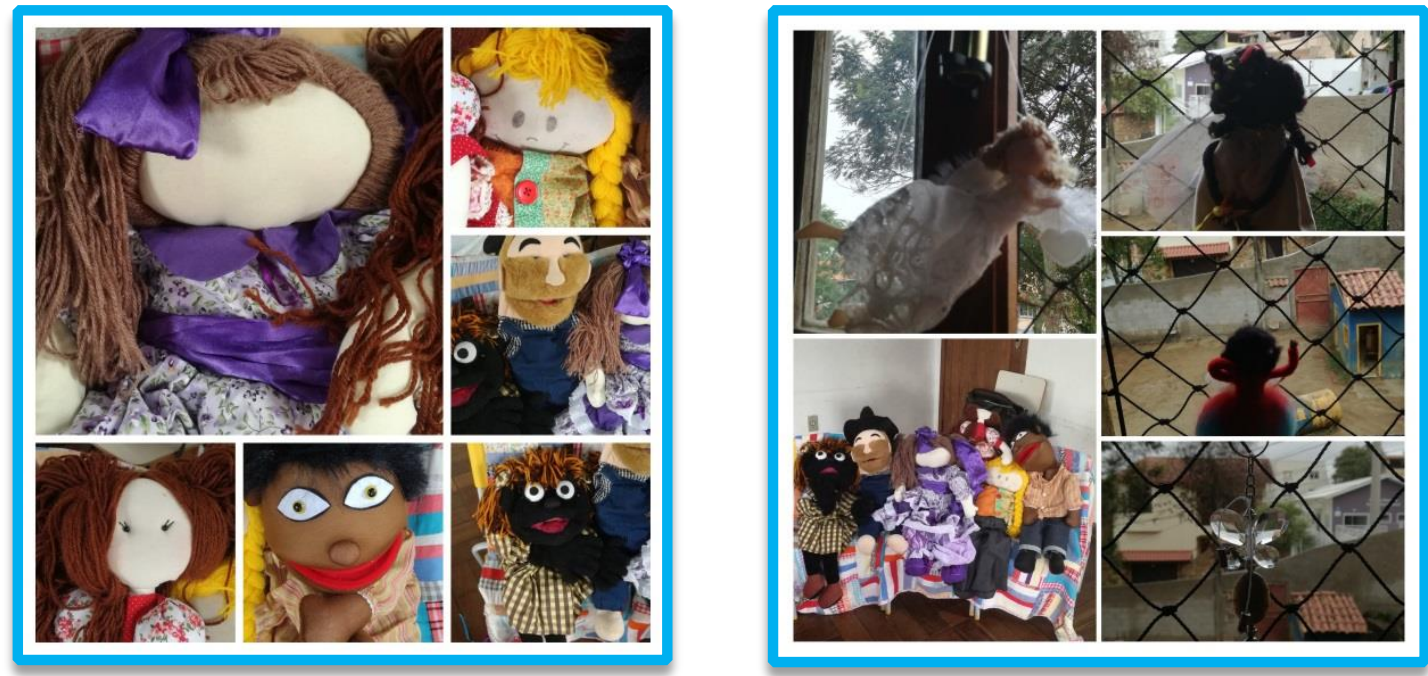

Fuente: Cuaderno de campo. Marcos Chica Díaz. Abril 2019.

FOTOS 08, 09, 10 E 11: A PREPARAÇÃO dOS CAVALOS.
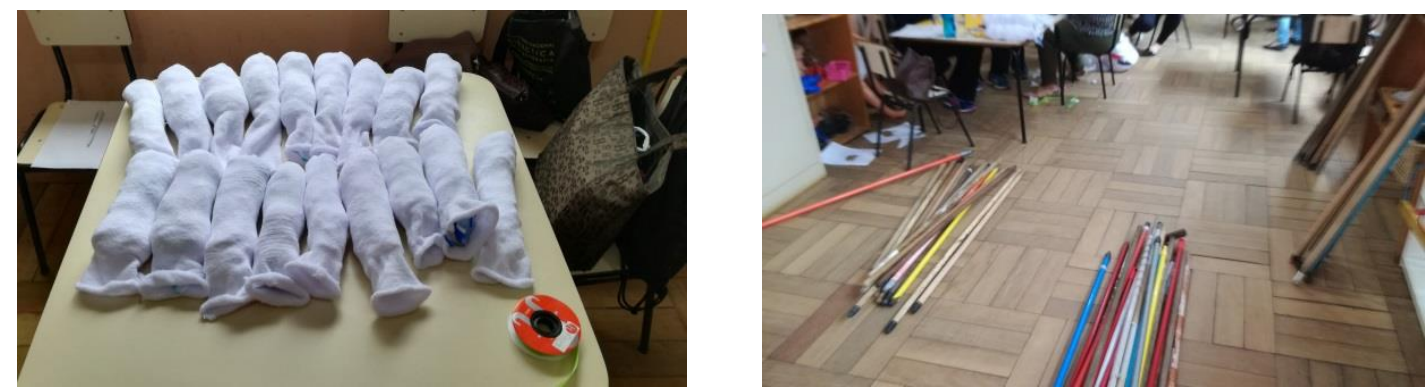


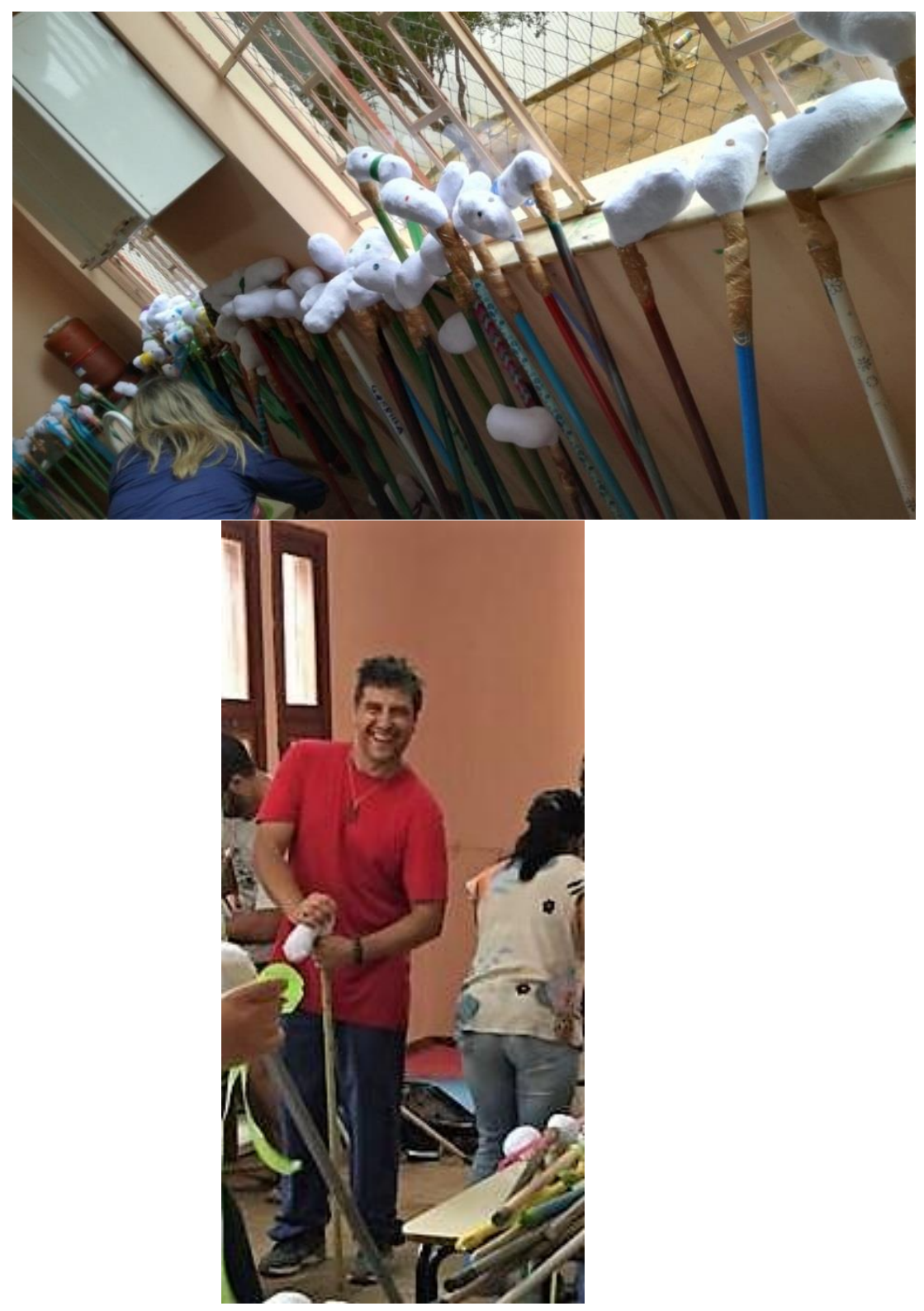

Fuente: Cuaderno de campo. Marcos Chica Díaz. Abril 2019.

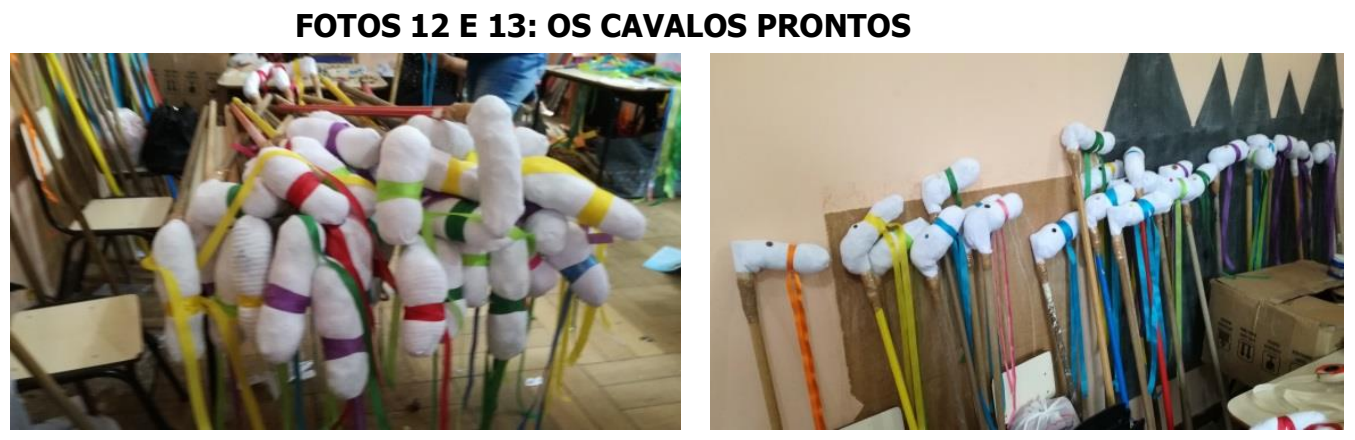

Fuente: Cuaderno de campo. Marcos Chica Díaz. Abril 2019. 


\section{FOTOS 14 E 15: PREPARANDO O ESPAÇO}
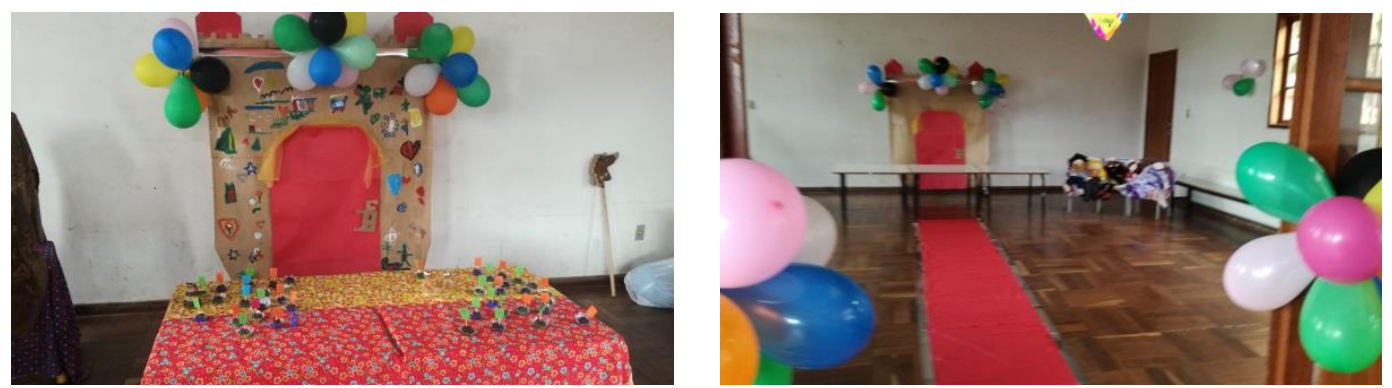

Fuente: Cuaderno de campo. Marcos Chica Díaz. Abril 2019.

\section{FOTOS 16 E 17: ENTREGA DOS CAVALOS.}
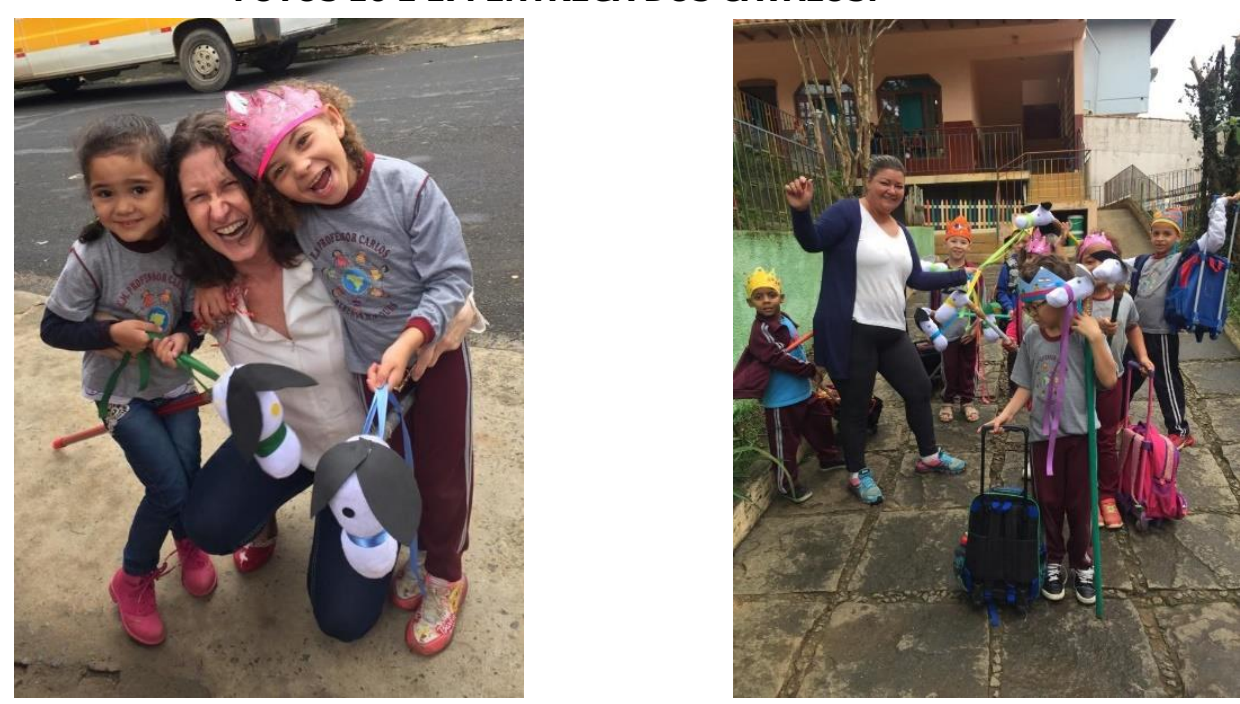

Arquivo Escola Carlos Alberto Marques -2019. 


\section{FOTOS 18 E 19: DIA DA CELEBRAÇÃo.}
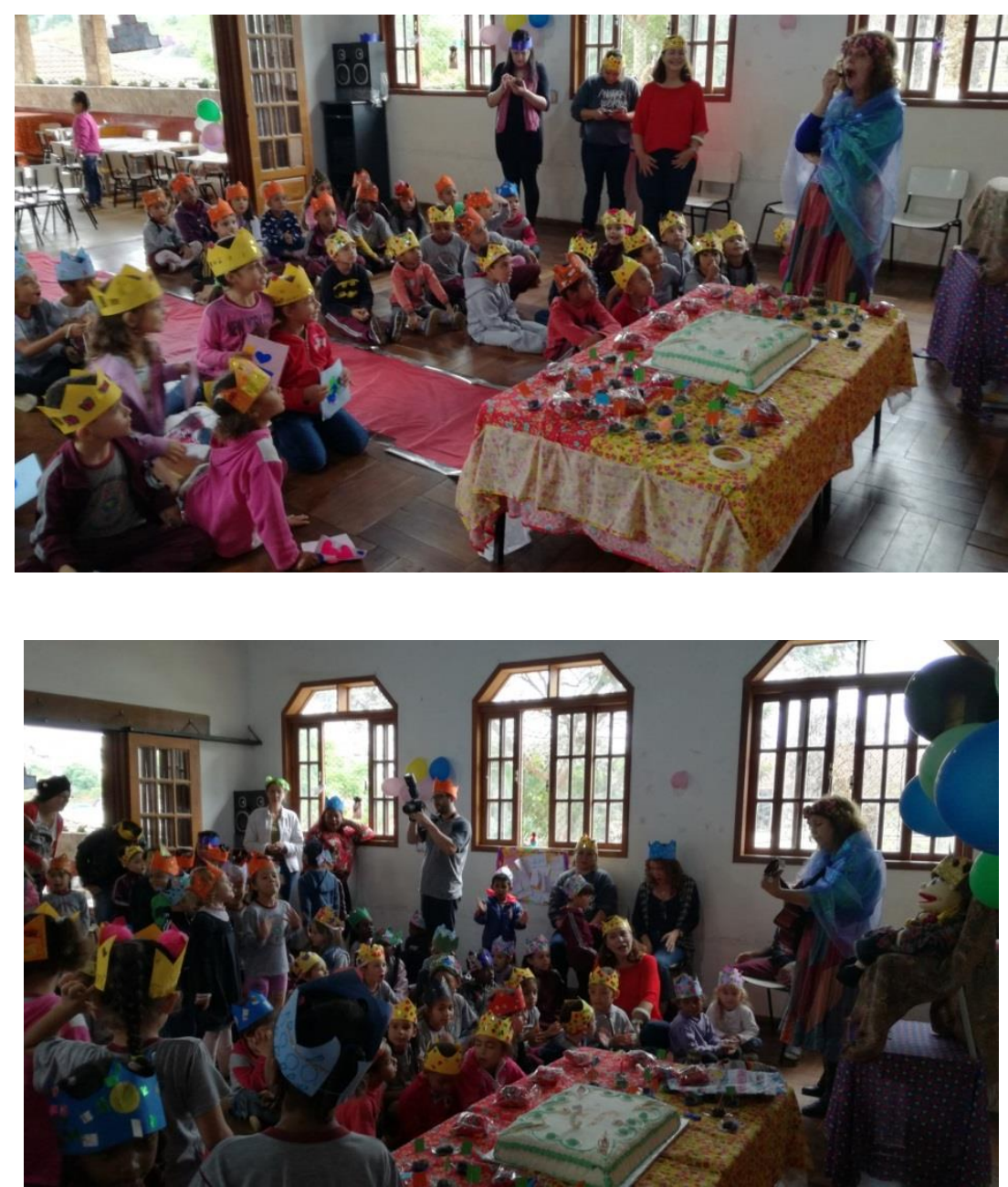

Fuente: Cuaderno de campo. Marcos Chica Díaz. Abril 2019.

Trouxemos esta narrativa não só pela beleza de sua vivência e por ter tocado de forma tão acentuada todos que dela participaram e, claro, também as crianças, mas porque ela explicita nossas escolhas e intenções como projeto de humanidade: o "renovar um mundo comum" (ARENDT, 1972, p. 247), esteja ele situado em qualquer lado do oceano Atlântico ou em qualquer canto desse planeta. Não com o desejo de pasteurizar, de anular a diversidade e as diferenças que nos constituem, mas de permitir o irromper aquilo que temos de mais humano: nosso ato de criação e renovação.

Por isso, deixamos o Zuza na imaginação de cada um. Na certeza de que alguém que, como ele, nasce no encontro da morte com a vida, estará a todo tempo nos lembrando que Zuza são os "sempres em nós" e os nós em encontros! Seja nas amorosidades entre humanos, seja nas amorosidades com os artefatos da cultura, seja nos abraços que laçam a existência humana em sua 
condição cultural e social. Começamos este texto com uma epígrafe e com um título, encerramos nossa narrativa com uma imagem. Que ela nos conte algo mais!

\section{FOTOS 20: O ABRAÇO}

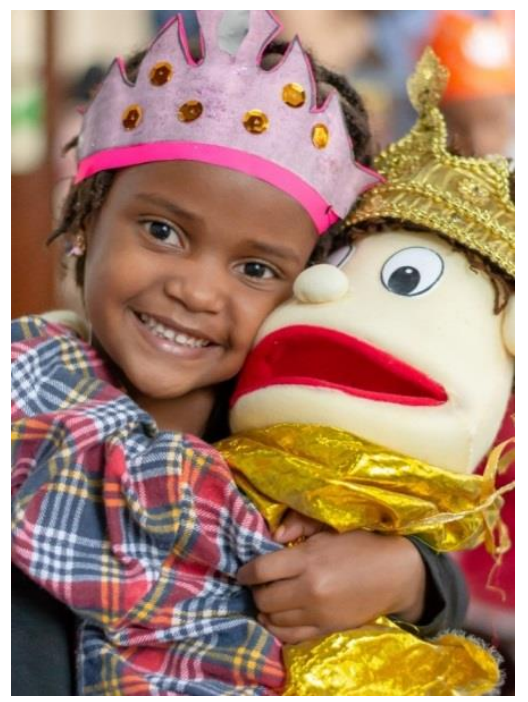

Arquivo pessoal Professora Nilcéia Beatriz Braga. Autor da foto: Filipe Cardoso

E ela nos conta: Zuza virou prínci(pio)pe! 


\section{REFERÊNCIAS:}

ARENDT, Hannah. A crise na educação: III e IV. Entre o passado e o futuro. São Paulo: Perspectiva, 1972. p. 247.

BAKHTIN, M.M. Para uma Filosofia do ato responsável. 2 ed. São Carlos: Pedro e João Editores, 2012.

O Homem no Espelho- Apontamentos de 1940. São Carlos: Pedro e João Editores, 2019.

Questões de Literatura e de Estética: a teoria do romance. São Paulo: Hecitec, 1993.

VIGOTSKI, L.S. Quarta aula: a questão do meio na pedologia. Disponível em: http://www.scielo.br/scielo.php?script=sci_arttext\&pid=S0103-65642010000400003

Imaginação e Criação na Infância. São Paulo: Expressão Popular.2018. 


\section{RESUMO}

Esse texto narra uma vivência. Uma experiência de encontros. Um desejo que uniu pessoas e artefatos culturais. Conta a vontade de um boneco que nasce da fronteira da vida e da morte e chega ao espaço de uma escola pública localizada no interior da Zona da Mata de Minas Gerais. É ai que estão as crianças. É um texto aberto! Que convida ao leitor a esse estar junto com as palavras e com muitas imagens que estão nesse espaçotempo que é gente fazendo e sendo. Não são fechamentos, formas de conceber. Mas são escolhas e criações.

Palavras-chaves: Vivência escolar. Crianças. Ser e Estar. Vida e Artefatos Culturais.

\section{RESUMEN}

Este texto narra una vivencia. Una experiencia de encuentros. Un deseo que unió a personas y artefactos culturales. Cuenta la voluntad de un títere nacido en la frontera entre la vida y la muerte; Así llega al espacio de una escuela pública ubicada dentro de la Zona de la Mata de Minas Gerais. Ahí es donde están los niños y niñas. iEs un texto abierto (libre)! Lo que invita al lector a estar junto a esas palabras e imágenes en ese mismo espacio-tiempo de personas que están siendo y haciendo. No son cerrados, son formas de concebir, pero son elecciones y creaciones propias.

Palabras clave: Vivencia escolar. Alumnos. Ser y estar. Vida y artefactos culturales.

\section{ABSTRACT}

This paper tells an experience. An encounter experience. A wish that united people and cultural artifacts. It tells the will of a doll that rises from the border of life and death and arrives at the space of a public school located inside the Zona da Mata of Minas Gerais. That's where the kids are. I;s an open text! That invites the reader to be together with the words and with many images that are in this space that is people doing and being. They are not closures, ways of conceiving. But they are choices and creations.

Keywords: School experience. Children. Being. Life and Cultural Artifacts.

Submetido em 30 de marco de 2019 Aprovado em de agosto de 2019 